\title{
EXCURSION TO THE CUTTING NEAR SHORTLANDS STATION ON THE NUNHEAD AND SHORTLANDS RAILWAY.
}

Saturday, April i ith, i89i.

Director: T. V. Holmes, F.G.S.

\author{
(Report by THE DIRector.)
}

Note.-The Sections to be seen in this cutting were described by the Director in some Notes read before the Geologists' Association on April 3rd, I89I ; the description then given is incorporated with the present Report.

Starting from the Nunhead Junction on the ILondon, Chatham and Dover Railway, the new line to Shortlands, ranging in a south-easterly direction, passes over the London and Brighton Railway and under the road between Deptford Cemetery and Brockley Hall, and crosses the Ravensbourne about 600 yards north of Catford Bridge Station on the South Eastern Railway. Thence its course is along the valley of the Ravensbourne till it joins the London, Chatham, and Dover main line about 500 yards north-west of Shortlands Station. (See Figs. I and 2.)

From Nunhead to the road that passes on the Western sides of Deptford Cemetery and of Brockley Hall the new line is on London Clay. At a point (Fig. I, l. c.) about midway between the road just mentioned and that connecting Brockley Hall with Ladywell the upper beds of the Woolwich Series are exposed; they form the surface for about 700 yards to the south-east when the London Clay again comes on (Fig. I, l.c.). This last-named junction is where the railway crosses a line of old trees, once in a hedgerow (see Fig. $\mathrm{r}$, and 6 in. Ordnance Map). Thence to the Ravensbourne the railway is on London Clay. Between the Ravensbourne and the road that connects Beckenham with Southend the line passes along the alluvial flat of the river; but, east of the lake, in the grounds of Beckenham Place, it begins to rise gradually to the level of the London, Chatham, and Dover main line. About half a mile from the junction, a cutting in the hillside west of the Ravensbourne exposes the whole of the beds belonging to the Woolwich Series together with a considerable thickness of the overlying Oldhaven or Blackheath beds.

Thus the parts of this new railway most worth a visit are east of Brockley Hall at the one end, and within three-quarters of a mile of Shortlands railway station at the other. Between them is a space of about three miles over which only river-gravel can be seen.

Where the line passes beneath the road that connects Brockley Hall and Deptford Cemetery, is a cutting in London 


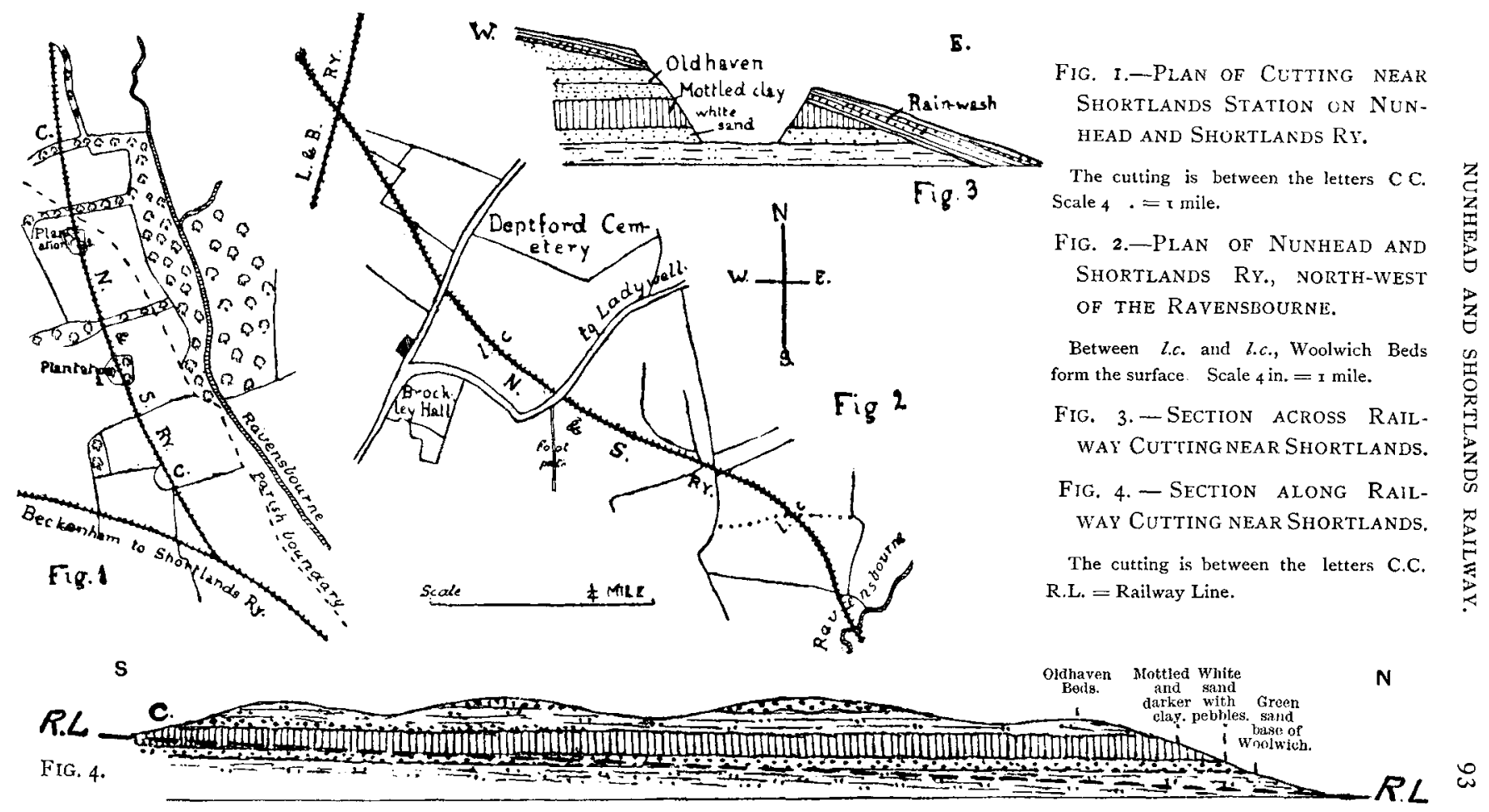


Clay. This rock thickens towards Nunhead, but rises in a southeasterly direction. Before reaching the first point marked $l$. c. in Fig. I, the pebble-band at the base of the London Clay, which appears to vary in thickness from five or six inches to two feet or more, rises to the surface. A few yards further to the south-east, yellowish sand is seen underlying the pebble-band, and the line, as it passes beneath the road to Ladywell, cuts through a considerable thickness of the Woolwich Beds. At the end of March, I891, the following section was exposed :-

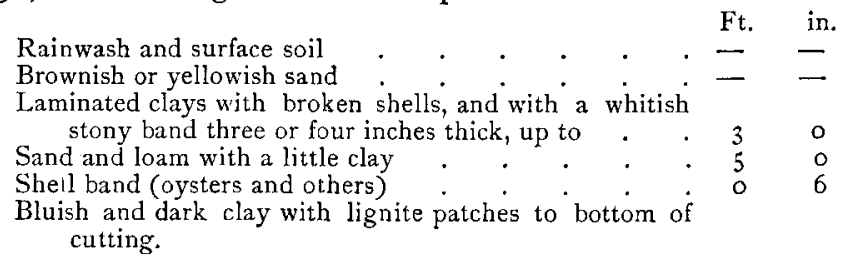

Two or three faults, with throws of eight or nine inches, were seen at this point. The shell-beds were visible in the cutting south of the road for a distance of more than roo yards.

At the second or south-easterly point marked $l$. c. in Fig. I, the London Clay is again in evidence and thickens in a southeasterly direction. Below it is the basement pebble-band, six or eight inches thick, and, beneath the pebble-band, about seven feet of yellowish sand. This appears to be nearly the full thickness here of the strata between the shell beds and the basement bed of the London Clay, which are represented at Loampit Hill by twenty-two or twenty-three feet.

In the course of the railway, for about three miles along the alluvial flat of the Ravensbourne, the occasional necessity of building a bridge, either for the passage of the new line over the South Eastern Railway or for that of a road over the new line, has caused much digging for foundations. The sections so formed sometimes show gravel from top to bottom; sometimes the uppermost two or three feet consist largely of clayey or loamy material, probably the inundation mud of the stream.

The cutting near Shortlands (Figs. 2, 3 and 4) is, from a geological point of view, the most interesting portion of the line. As the railway rises southward more rapidly than do the beds traversed, the lowest strata are seen only toward the northern end of the cutting.

Forming the floor of the cutting at the point at which a bridge crosses the line, is a dark green sandy bed with occasional pebbles and with an oyster band. This is evidently the bottom bed of the Woolwich Series in this locality; for at Beckenham Brewery, "green sand and black pebbles," to the thickness of eight feet, were found resting on the Thanet Sands, while at Clay Hill, only about half a mile south-west of this cutting, a similar green sand 
bed was found in the same position. This green sand bottom bed is, in fact, one of the most constant of the variable Woolwich and Reading Series. The greatest thickness of this bed seen in the cutting was about seven feet six inches.

Above the green sand comes a bed of white or whitish sand with black flint pebbles; this forms the floor of the cutting in a southerly direction and is from four to five feet thick.

Next follows the clay with shells, chiefly Cyrena. At the southern end of the cutting this bed consists of mottled clay towards the base and darker clay with shells above; but northward the colour of the clay and the thickness of the bed seem to vary; the mottled clay, however, where visible, is always at the base. The greatest measurement of the thickness of this bed was eight feet six inches.

Above the clay with shells, at the southern end of the cutting is a pebble bed apparently belonging to the Blackheath Series; it is from four to five feet thick, and mixed with fragments of broken shells. Resting on this are whitish or yellowish sandy and loamy beds which vary much in detail. Where the railway traverses the more southerly of the two little square plantations, the pebble bed with broken shells was seen to be less than two feet thick, and on it was resting ten feet or more of sand with loamy and clayey partings. At the more northerly of the two plantations, a second pebble bed, with few broken shells, but with the pebbles largely cemented into a conglomerate, appeared above the sand and loam to a thickness of eight feet.

At the southern end of the cutting, the mottled clay forms the floor; but in a hole made to a depth of about two feet six inches below that level could be seen the underlying white sand and pebbles so conspicuous northward.

About midway between the two little plantations, and on the eastern or valley side of the cutting, though a few yards away from it, a pit was dug which showed six or seven feet of rather loose orange-coloured sand. Its position inclined one to think that this sand might be the upper part of the Thanet Sands. It did not, however, present the usual appearance of that bed, and Mr. Whitaker, when he visited the section, was quite sure that it was only a valley deposit. To those Members who joined the excursion the correctness of this view was proved by a deep drain, which had been cut from a point near the southern end of the cutting, down the hill-side in an easterly direction. The sides of the excavation were much timbered, but the material thrown up showed that the white sand with black pebbles and the underlying green sand, which lie below the level of the cutting at this end, had both been passed through, and that Thanet Sand of ordinary appearance had been reached.

To the geological surveyor, the present section is of interest as establishing the presence of Woolwich Beds in considerable 
thickness along this hillside. Here, at least, they were not eroded away before the deposition of the overlying Oldhaven or Blackheath Beds, as was the case in some other localities; at the southernmost end of the Chislehurst station cutting, for instance, two miles to the east, the pebble beds have scooped down to the Thanet Sands.* Although Woolwich Beds are drawn in the Survey Map as occurring on the hillside west of Hayes Common, and between Hayes Common and Croydon, they do not appear to have been detected hitherto on the slopes bordering the Ravensbourne Valley south of Hayes. Diggings to a depth of five or six feet over the site of the cutting would have revealed nothing but Oldbaven Beds, and rainwash from the London Clay that caps the hill. (See Fig. 4.)

A cutting like that here described, needs many exploratory visits. For, in the first place, a cutting that traverses soft, incoherent beds, seldom, if ever, presents a clear section for more than a very short horizontal or vertical extent : the actual spot at which work is being done may be clear, but a few yards away everything nay be obscured, either by the action of the weather or by that of man in sloping the sides. In the second place, when a cutting skirts a hill, a clear section on the valley side will show surface beds of a very different kind from those exposed on the other side. This is due to the wash of material down the hill-side, and to the sorting action of the water, which frequently imparts such uniformity of character to this rainwash for a short distance as to disguise its true nature and to give it a delusive appearance of being in situ. Since, moreover, the higher side of a cutting, which might have afforded evidence correcting the erroneous notions derived from inspection of the other side, is the first to be sloped, and its sections hidden or obscured, this possible source of error seems worth pointing out.

For convenience sake, the above description has followed the course of the line from north to south: the members, however, made its acquaintance in the reverse direction. Proceeding from Shortlands railway station, which they reached about 3.30 p.m., they saw successively the shell beds of the Woolwich Series, the overlying pebble beds of the Blackheath Series, and then, towards the northern end, the mottled clay at the base of the shell beds, and, below this, the beds of white sand with pebbles, and the green sand or basement bed of the Woolwich Series.

On leaving the cutting, the party passed through the recreation ground of Bromley, and visited the graveyard of the old parish church, where some remarkable epitaphs on or near the southern wall of the church detained them a few moments. They then refreshed themselves with tea at the Bell Hotel, Bromley, at six p.m.

A visit to this cutting on June $26 \mathrm{th}, \mathrm{I} 89 \mathrm{I}$, showed that, where

*Whitaker, "Geology of London," vol i., p. I64. 
the bridge crosses the line near the northern end of the cutting, there had been much excavation in the upper, or thicker, pebble bed, in order to make approaches to the bridge on the western side of the line. There were seen many masses of pebbles cemented together, the masses occurring in a curiously irregular manner. Though the section as a whole had deteriorated in consequence of the sloping of the sides of the cutting, this part of it in the pebble beds was far finer than any seen on former occasions.

REFERENCES.

Geological Survey Map, Sheet 6, Drift Edition, or

"London and its Environs" Drift Edition. 1889. W. WhitAKer. " "Geology of London," Mem. Geol. Surv.

VISIT TO THE ZOOLOGICAL GARDENS.

SatUrday, April 25Th, I89I.

Directors: P. L. Sclater, Ph.D., F.R.S., and G. A. Bovlenger, F.Z.S.

By kind permission of the Council of the Zoological Society, Members of the Association were admitted to the Gardens after two p.m., free of charge, by the principal entrance in the outer circle, upon producing their Excursion Circular and signing their names.

At three p.m. the party assembled at the Lion-house, where Dr. Sclater gave a short discourse on "The Larger Cats." They then proceeded to the Reptile-house and had its more interesting features pointed out to them by Mr. Boulenger.

A vote of thanks to the two Directors brought a successful afternoon to its close.

\section{EXCURSION TO GUILDFORD. \\ Saturday, May 2 ND, i8gi.}

Directors: Lieut.-Col. Godwin-Austen, F.R.S., Horace W. Monckton, F.G.S., and R. S. Herries, M.A., F.G.S.

$$
\text { (Refort by Mr. MONCKTON.) }
$$

The party assembled at Guildford station at $\mathbf{1} 2.3 \circ$ p.m., and walked to the old quarry in Bargate Stone, from which Mr. Meyer formerly obtained a large collection of fossils. It is on the west of the footpath from Braboeuf House to Orange Grove, and one mile south-west of Guildford Castle. The quarry itself is now disused, but a smaller pit a little to the west, which is still worked, was visited. 